\title{
GLOBAL IMPLEMENTATION OF THE WORLD HEALTH ORGANIZATION'S INTERNATIONAL CLASSIFICATION OF DISEASES (ICD)-11: THE ALLERGIC AND HYPERSENSITIVITY CONDITIONS MODEL
}

LUCIANA TANNO ${ }^{1}$, Robert Chalmers ${ }^{2}$, Robert Jakob ${ }^{2}$, Nenad Kostanjsek ${ }^{2}$, Ana Luiza Bierrenbach ${ }^{1}$, Bryan Martin ${ }^{3}$, Nicolas Molinari ${ }^{4}$, Isabella Annesi ${ }^{5}$, Nikolaos Papadopoulos ${ }^{6}$, Mario Sanchez-Borges ${ }^{7}$, Lanny Rosenwasser ${ }^{8}$, Ignacio J Ansotegui ${ }^{9}$, Motohiro Ebisawa ${ }^{10}$, Juan Carlos Sisul ${ }^{11}$, Edgardo Jares ${ }^{12}$, Maximiliano Gómez ${ }^{13}$, Ioana Agache ${ }^{14}$, Antonella Muraro $^{15}$, Gary Wong ${ }^{16}$, Francis Thien ${ }^{17}$, Ruby Pawankar ${ }^{18}$, Tood Mahr ${ }^{19}$, JAMES Sublett $^{20}$, David Lang ${ }^{21}$, Thomas Casale ${ }^{22}$, and Pascal Demoly ${ }^{23}$

${ }^{1}$ Hospital Sírio Libanês

${ }^{2}$ World Health Organization

${ }^{3}$ Columbus State University

${ }^{4}$ service DIM

${ }^{5}$ EPAR U707 INSERM

${ }^{6}$ Second Pediatric Clinic

${ }^{7}$ Centro Medico-Docente La Trinidad

${ }^{8}$ Children's Mercy Hospitals and Clinics

${ }^{9}$ Hospital Quironsalud Bizkaia

${ }^{10}$ National Hospital Organization, Sagamihara National Hospital

${ }^{11}$ Latin American Society of Allergy, Asthma and Immunology

${ }^{12}$ LIBRA Foundation and CMP SA

${ }^{13}$ Fundación Ayre

${ }^{14}$ Transylvania University of Brasov

${ }^{15}$ Padua General University Hospital

${ }^{16}$ Chinese University of Hong Kong

${ }^{17}$ Monash University

${ }^{18}$ Nippon Medical School

${ }^{19}$ Gundersen Health System in La Crosse

${ }^{20}$ UNIVERSITY OF LOUISVILLE SCHOOL OF MEDICINE

${ }^{21}$ Department of Allergy

${ }^{22}$ University of South Florida

${ }^{23}$ University Hospital of Montpellier

May 18, 2020 


\begin{abstract}
The International Classification of Diseases (ICD) provides a common language for use worldwide as a diagnostic and classification tool for epidemiology, clinical purposes and health management. Since its first edition, the ICD has maintained a framework distributing conditions according to topography, with the result that some complex conditions, such as allergies and hypersensitivity disorders $(\mathrm{A} / \mathrm{H})$ including anaphylaxis, have been poorly represented. The change in hierarchy in ICD-11 permitted the construction of the pioneer section addressed to $\mathrm{A} / \mathrm{H}$, which may result in more accurate mortality and morbidity statistics, including more accurate accounting for mortality due to anaphylaxis, strengthen classification, terminology and definitions. The ICD-11 was presented and adopted by the 72nd World Health Assembly in May 2019 and the implementation is ongoing worldwide. We here present the outcomes from an online survey undertaken to reach out the allergy community worldwide in order to peer review the terminology, classification and definitions of A/H introduced into ICD-11 and to support their global implementation. Data are presented here for 406 respondents from 74 countries. All of the sub-sections of the new A/H section of the ICD-11 had been considered with good accuracy by the majority of respondents. We believe that, in addition to help during the implementation phase, all the comments provided will help to improve the $\mathrm{A} / \mathrm{H}$ classification and to increase awareness by different disciplines of what actions are needed to ensure more accurate epidemiological data and better clinical management of $\mathrm{A} / \mathrm{H}$ patients.
\end{abstract}

GLOBAL IMPLEMENTATION OF THE WORLD HEALTH ORGANIZATION'S INTERNATIONAL CLASSIFICATION OF DISEASES (ICD)-11: THE ALLERGIC AND HYPERSENSITIVITY CONDITIONS MODEL

Luciana Kase Tanno ${ }^{1,2,3,4,5^{*}}$, Robert Chalmers ${ }^{5,6}$, Robert Jacob ${ }^{7}$, Nenad Kostanjsek ${ }^{7}$, Ana Luiza Bierrenbach $^{1,8}$, Bryan Martin ${ }^{9}$, Nicolas Molinari ${ }^{10}$, Isabella Annesi-Maesano ${ }^{3}$, Nikolaos G. Papadopoulos ${ }^{11}$, Mario Sanchez-Borges ${ }^{12}$, Lanny J Rosenwasser ${ }^{13}$, Ignacio Ansontegui ${ }^{14}$, Motohiro Ebisawa ${ }^{15}$, Juan Carlos Sisul $^{16}$, Edgardo Jares ${ }^{17}$, Maximiliano Gomez ${ }^{18}$, Ioana Agache ${ }^{19}$, Antonella Muraro ${ }^{20}$, Gary WK Wong ${ }^{21}$, Francis Thien ${ }^{22,23}$, Ruby Pawankar ${ }^{24}$, Todd A. Mahr ${ }^{25}$, James L. Sublett ${ }^{26}$, David M Lang ${ }^{27}$, Thomas Casale $^{28}$, Pascal Demoly ${ }^{2,3,4}$, and on behalf of the Joint Allergy Academies**

1 Hospital Sírio-Libanês

2 University Hospital of Montpellier, Montpellier, France

3 Sorbonne Université, INSERM UMR-S 1136, IPLESP, Equipe EPAR, 75013, Paris, France

4 WHO Collaborating Centre on Scientific Classification Support, Montpellier, France

5 ICD-11 Medical and Scientific Advisory Committee, WHO, Geneva

6 Centre for Dermatology, University of Manchester, UK

7 Classifications, Terminologies and Standards, World Health Organization, Geneva, Switzerland.

8 Sanas Epidemiology and Research, São Paulo, and Teaching Research Institute (IEP), Hospital Sírio Libanês, São Paulo, Brazil

9 Medicine and Pediatrics, The Ohio State University in Columbus, Ohio, USA

10 IMAG UMR 5149, DIM CHRU de Montpellier, France

11 Centre for Paediatrics and Child Health, Institute of Human Development, University of Manchester, United Kingdon and Department of Allergy, 2nd Pediatric Clinic, University of Athens, Athens, Greece

12 Allergy and Clinical Immunology Department, Centro Medico Docente La Trinidad, Caracas, Venezuela

13 Department of Pediatrics, Division of Immunology Research, Children's Mercy Hospitals \& Clinics, Kansas City, MO 64108, USA

14 Department of Allergy and Immunology, Hospital Quirónsalud Bizkaia Erandio, Bilbao, Spain

15 Clinical Research Center for Allergy and Rheumatology, Sagamihara National Hospital, Japan 
16 Past President of the Latinalerican Society of Allergy, Asthma and Immunology and fellow of the American College of Allergy, Asthma and Immunology, Paraguay

17 LIBRA Foundation and CMP SA Buenos Aires, Argentina

18 Research \& Education, Fundación Ayre. Allergy \& Asthma Unit, Hospital San Bernardo. Salta, Catholic University of Salta, Argentina.

19 Transylvania University, Brasov, Romania

20 Food Allergy Referral Centre Veneto Region, Department of Women and Child Health, Padua General University Hospital, Padua, Italy

21 Department of Pediatrics, Chinese University of Hong Kong, Hong Kong, China

22 Faculty of Medicine, Nursing and Health Sciences, Monash University, Clayton, Vic Australia

23 Department of Respiratory Medicine, Eastern Health, Vic, Boxhill, Australia

24 Department of Pediatrics, Nippon Medical School, Tokyo, Japan.

25 Pediatric allergy and clinical immunology, Gundersen Health System in La Crosse, USA

26 Managing Partner, Family Allergy \& Asthma; Clinical Professor, Section of Allergy \& Immunology, Department of Pediatrics, University of Louisville School of Medicine, Louisville, KY USA

27 Department of Allergy and Clinical Immunology, Respiratory Institute, Cleveland Clinic, Ohio, USA

28 Morsani College of Medicine, University of South Florida, Tampa, FL, USA

* Corresponding author: Luciana Kase Tanno MD, PhD, Division of Allergy, Department of Pulmonology, Hôpital Arnaud de Villeneuve, University Hospital of Montpellier, 371, av. du Doyen Gaston Giraud - 34295, Montpellier cedex 5, France. Tel.: +33 467336107 Fax: +33 467633645

E-mail: luciana.tanno@gmail.com

** Joint Allergy Academies: American Academy of Allergy Asthma and Immunology (AAAAI), European Academy of Allergy and Clinical Immunology (EAACI), World Allergy Organization (WAO), American College of Allergy Asthma and Immunology (ACAAI), Asia Pacific Association of Allergy, Asthma and Clinical Immunology (APAAACI), Asia Pacific Academy of Pediatric Allergy, Respirology \& Immunology (APAPARI), Latin American Society of Allergy, Asthma and Immunology (SLAAI)

\section{ABSTRACT}

The International Classification of Diseases (ICD) provides a common language for use worldwide as a diagnostic and classification tool for epidemiology, clinical purposes and health management. Since its first edition, the ICD has maintained a framework distributing conditions according to topography, with the result that some complex conditions, such as allergies and hypersensitivity disorders $(\mathrm{A} / \mathrm{H})$ including anaphylaxis, have been poorly represented.

The change in hierarchy in ICD-11 permitted the construction of the pioneer section addressed to A/H, which may result in more accurate mortality and morbidity statistics, including more accurate accounting for mortality due to anaphylaxis, strengthen classification, terminology and definitions. The ICD-11 was presented and adopted by the $72^{\text {nd }}$ World Health Assembly in May 2019 and the implementation is ongoing worldwide.

We here present the outcomes from an online survey undertaken to reach out the allergy community worldwide in order to peer review the terminology, classification and definitions of A/H introduced into ICD-11 and to support their global implementation. Data are presented here for 406 respondents from 74 countries. All of the sub-sections of the new A/H section of the ICD-11 had been considered with good accuracy by the majority of respondents. 
We believe that, in addition to help during the implementation phase, all the comments provided will help to improve the $\mathrm{A} / \mathrm{H}$ classification and to increase awareness by different disciplines of what actions are needed to ensure more accurate epidemiological data and better clinical management of $\mathrm{A} / \mathrm{H}$ patients.

KEY WORDS: allergy, classification, definition, hypersensitivity, International Classification of Diseases, implementation, terminology, World Health Organization

\section{THE SCOPE OF THE PROBLEM}

\section{The World Health Organization International Classification of Diseases (ICD)}

The fields of health terminology, classification, ontology, and related information models have evolved dramatically over the last 25 years (1) and the increasing demands and uses of information has also transformed the process of coding. A standard registry of morbidity and mortality data provides health information for statistics and epidemiology, health care management, allocation of resources, monitoring and evaluation of research, and for disease prevention and treatment. This information need has given rise to a process of coding, whereby words describing medical conditions are translated into codes (2).

The International Classification of Diseases (ICD) is maintained by the World Health Organization (WHO) and provides a common language for use worldwide as a diagnostic and classification tool for epidemiology, clinical purposes and health management. It enables the analysis of the general health situation of different population groups and provides data on the key problems to be managed. It is used to classify diseases registries for many types of health and administrative purposes including death certificates and electronic health care records. In addition to enabling the storage and retrieval of diagnostic information for clinical, epidemiological and quality purposes, including the needs of payers and Health Technology Assessment bodies, these reported data also provide the basis for compilation of national mortality and morbidity statistics (MMS) by WHO Member States $(2,3)$.

The first edition of the ICD was published in 1893 (4). This classification distinguished between systemic diseases and those localized to a particular organ or anatomical site (5). The ICD has thus far maintained a similar framework, distributing conditions according to topography (5), with the result that some complex conditions, such as allergies including anaphylaxis, have been poorly represented.

The ICD has been periodically revised, with most countries now using the tenth revision (ICD-10) or national adaptations thereof (3). It is used by more than 100 countries, is available in 43 different languages and is the tool used for allocating about $70 \%$ of the world's health expenditure. In the US alone this amounted in 2017 to USD $\$ 3.5$ trillions according to the National Center for Health Statistics (6-8). Therefore, modification of the ICD framework has the potential to have an impact on health financing and economics. On the other hand, the misclassification or underrepresentation of specific disorders in this global classification system can lead to lack of visibility, investment and public health action, as proved for allergic and hypersensitivity conditions $(9,10)$.

The need for a better representation of allergic and hypersensitivity conditions in the ICD

Originally perceived as secondary disorders by most of health professionals, $\mathrm{A} / \mathrm{H}$ represent one of the fastest growing group of conditions worldwide and have become a major public health problem . It is estimated that more than 150 million Europeans and over 25 to $30 \%$ of the world's population are affected by these conditions (11,12). The Asthma and Allergy Foundation states that allergy affects one in five citizens (6) and accounts for more than 17 million outpatient office visits per year in the Unites States of America alone (7). The estimated annual cost of allergies is nearly $\$ 7$ billions (6). Allergies now represent the fourth most common chronic disease category in the world $(6,12)$. WHO predicts that in 2050, 1 in 2 people in the world will suffer from allergies with a steady increase, especially in industrialized countries. In France, the number of people suffering from an allergy has doubled in 20 years, especially among children and adolescents $(8,11$ 13). Proper documentation, classification and coding of patients' allergy information is vital to support their care, safety, and education. However, A/H have never been well classified and coded in the ICD 
. The current classification framework, ICD-10, presents conceptual and operational failures for A/H, as demonstrated and published in Brazil for anaphylaxis (10).

\section{The ICD-11 revision}

In development since 2007, ICD-11 is intended not only to rectify deficiencies in ICD-10 and to incorporate changes demanded by scientific advances, but also to take advantage of the revolution in electronic data handling since the publication of ICD-10 a quarter of a century ago.

ICD-11 is regarded as a suite of classifications, which is based on a detailed and comprehensive polyhierarchical web-like foundation in which any single disease entity may be represented in more than one location (3). The innovatory electronic authoring and browsing platforms developed for the ICD Revision Project enabled ICD-11 to be assembled and refined in a sophisticated manner including metadata such as definitions, synonyms and causal mechanisms for each concept and support for a complex polyhierarchical structure.

From this foundation may be extracted any number of traditional tabular lists, which differ from the foundation in that a single entity may appear in only one location as in ICD-10. This also permitted the construction of a range of specialist classifications in which the detail contained in the foundation is retained but which can be linked to ICD-11 (14).

\section{THE WORLD NEEDS BETTER HEALTH DATA}

\section{The Allergy in ICD-11 initiative}

Over the past 7 years, a detailed action plan was developed and implemented under the ALLERGY in ICD-11 initiative (led by LKT and PD) with the aim of creating a more appropriate classification for $\mathrm{A} / \mathrm{H}$ conditions in this new edition of ICD. Through its academic work in providing scientific and technical evidence, it has been possible to get in touch with the WHO and its representatives of the need for change in the representation of $\mathrm{A} / \mathrm{H}$ disorders in the $11^{\text {th }}$ revision. The continuing close collaboration between our group and WHO has the backing of 6 international regional allergy academies, named Joint Allergy Academies. (15). The core Allergy in ICD-11 operational team (LKT and PD) is an independent non-profit group working for the Allergy specialty worldwide and represents the Joint Allergy Academies into the ICD-11 and other WHO classifications.

The main outcome of this process has been the construction of the pioneering Allergic and hypersensitivity conditionssection within the newly created chapter, Disorders of the Immune System, which has been incorporated into ICD-11. All the evidence-based academic process has been documented in peer-reviewed publications $(2,9,10,13,15-40)$.

The new framework addressing A/H conditions underwent extensive field-testing (30) and quality assurance (25-27), demonstrating that use of the ICD-11 MMS resulted in a clear increase in the frequency of accurate coding for these conditions when compared with ICD-10. Furthermore, ICD-11 enables diagnoses to be linked to a range of parameters by the addition of one or more "extensions", classified under the "Extension codes" $\mathrm{X}$ chapter in a process termed post-coordination (14). WHO has been promoting this classification strategy in which a stem entity (e.g. Anaphylaxis) can be more fully defined by linking it to a range of different value sets including severity, anatomical location and causal agent.

We were also able to enhance changes in the WHO mortality coding rules by including anaphylaxis as underlying cause of death in official death certificates, which will contribute to more accurate mortality data in the years to come. Since the ICD-11 may allow giving more details to the conditions by combining with characteristics, it will now be possible to provide more data related to the deaths when they are available, such as severity, etiology.

The ICD-11 was presented and adopted by the $72^{\text {nd }}$ World Health Assembly in May 2019 and the implementation of this new classification is ongoing worldwide (41). Although ICD-11 will come into effect in $1^{\text {st }}$ January 2022, some countries such as the US may take longer to fully adopt ICD-11. 


\section{The Montpellier WHO Collaborating Centre for Classification Scientific Support}

In June 2018, the WHO Collaborating Center (WHO CC) for the Scientific Classification Support (CSS) was established at the University Hospital of Montpellier, headed by LKT and PD (42). This designation is the result of recognition by WHO of all the efforts of the ALLERGY in ICD-11 initiative and is intended to provide academic, research and scientific support to WHO in the implementation, refinement and maintenance of the WHO-FIC in the areas of our expertise. Furthermore, LKT has been co-opted by WHO into the small Medical and Scientific Advisory Board recently created to support the maintenance of ICD-11 and other WHO FIC classifications (43).

The WHO-FIC (Family of International Classifications) Network CC also assists WHO in the revision and development of ICD and other WHO reference classifications (38). The Montpellier WHO CC for A/H is involved in national and international initiatives in order to ensure quality implementation of ICD-11 and other WHO international classifications, taking $\mathrm{A} / \mathrm{H}$ as a model. These include education modules to support quality of classification and coding under the new framework and collaboration work with other institutions. In this context, we here present the outcomes of a engagement process involving the allergy community in which the principal terms and definitions of the pioneer Allergic and hypersensitivity conditions section of the ICD-11 could be scrutinised. This step is critical for the implementation process by strengthening awareness and preparing the allergy community for ICD-11.

\section{ONE VOICE FOR THE ALLERGY COMMUNITY IN THE IMPLEMENTATION OF THE ICD-11}

To reach out the allergy community worldwide, we developed a web-based survey in English, which was launched via Internet and circulated for 7 weeks (August to October 2019). The survey was anonymous and voluntary. An online questionnaire was constructed using GoogleDocs ${ }^{\mathrm{R}}$, enabling responses to be recorded in a unique database. We sent out an introduction letter containing a link to the questionnaire unique to each participating member. We received help from a number of relevant international and national academies in distributing the survey among their members. The link directed respondents to a page explaining the purpose of the survey. A reminder was sent out after 4 weeks. The survey has been disseminated by e-mail and by social media.

Of the 35 questions, 6 related to the utility of ICD and 15 to the content of the Allergic and hypersensitivity conditions section, specifically the nomenclature and definitions of the main conditions in each of the 6 principal domains: i) allergic or hypersensitivity disorders involving the respiratory tract; ii) allergic or hypersensitivity disorders involving the eye; iii) allergic or hypersensitivity disorders involving the skin and mucous membranes; iv) allergic or hypersensitivity disorders involving the digestive tract; v) anaphylaxis; and vi) complex allergy disorders (drug, food and Hymenoptera hypersensitivity) (Annex 1).

The following numeric scoring system was used: 0 (not at all accurate), 1 (low accuracy, but possible to use), 2 (acceptable accuracy), 3 (good accuracy) and 4 (extremely accurate). We originally planned to analyse the responses for each of the 6 domains but realised on receipt of the responses that it would be necessary to amalgamate some domains in order to facilitate the communication of the results.

Engaging the allergy community: what the ICD-11 can bring us?

Data are presented here for the 406 respondents (Table 1) from 74 countries who completed the survey (Figure 1). The countries were aggregated according to the six WHO global regions - AFRO (primarily subSaharan Africa), PAHO (the Americas), EMRO (Eastern Mediterranean/North Africa), EURO (Europe), SEARO (Southeast Asia), and WPRO (Western Pacific) - and across the global sample. Table 1 provides a list of participating countries, number of participants from each allergy society, mean age of respondents, sex ratio, specialty, professional experience, percent of professionals who spend more than 20 hours/week looking after patients suffering from $\mathrm{A} / \mathrm{H}$ diseases, working setting, information relating to coding practice in day-to-day clinical work and a rating of the appropriateness of the classification system in use. As shown in Figure 1 and Table 1, all WHO global regions were represented in the survey. Response rates were lowest for AFRO (1.7\%) and highest for EURO (46.5\%). 
Allergists with long-time professional experience working in private and/or public settings were the principal respondents to the survey and $97 \%$ of these reported seeing allergic patients regularly (Table 1); $71 \%$ of this group reported having more than 10 years of professional experience in $\mathrm{A} / \mathrm{H}$ and nearly two thirds $(64.5 \%)$ spent more than 20 hours per week seeing $\mathrm{A} / \mathrm{H}$ patients.

As shown in Table 1, 59\% of the respondents use ICD-10 or national adaptations thereof in their daily clinical work; $11.4 \%$, mainly from the AFRO region, use ICD-9 or its national adaptations. A high proportion of respondents $(72.2 \%)$ from the EMRO region do not use any classification/ coding system. $56.9 \%$ of the respondents mentioned that they were personally responsible for coding diseases/interventions in their practice and $25.1 \%$ reported that a staff member of their practice or institution perform this task.

From overall responses, the main utility of a classification and coding system was judged to be the "basis for generating national health statistics", followed by "to support communication between clinicians". The responses differed according to the world regions (Figure 2). For instance, most of participants from the SEARO region use the classification for "communication with the payers" whereas ERMRO representatives use it for "communication between clinicians and patients".

Although ICD-10 was shown to be the classification system most used worldwide, $69.5 \%$ of users did not consider it appropriate for clinical practice. The participants highlighted the need for inclusion of missing allergic diseases $(75.3 \%)$ and the presence of diseases with overlapping classification (e.g., Asthma induced by Aspirin) (64\%). In response to these needs, the respondents were aware that ICD-11 will allow more accurate representation of $\mathrm{A} / \mathrm{H}(77.1 \%)$, will support harmonization of terminology and definitions in the field of allergy (56.9\%) and will be able to support correct diagnosis and management (49.5\%) (Table 2).

\section{Harmonizing allergy and hypersensitivity nomenclature and definitions}

As demonstrated in Figure 2, we observed a similar pattern of responses relating to the accuracy evaluation of the new ICD-11 Allergic and hypersensitivity conditions classification. All of the sections had the score 3 (good accuracy) selected by the majority of respondents.

The nomenclature and definitions of "allergic rhinitis", "allergic asthma" and "anaphylaxis" received the best scores (3 and/or 4). On the other hand, in contrast with other sections, "Dermatitis or eczema", "non-allergic asthma" and the "Allergic or hypersensitivity reactions to arthropods" subsection presented higher proportion of scores 1 and 2 (Figure 2). We received 49 responses to open questions with suggestions covering missing conditions (e.g ., primary immunodeficiency), inclusion of underlying mechanism or causes and requests for simplification of the section.

\section{LESSONS FROM THE ENGAGEMENT PROCESS}

The implementation phase of ICD-11 is currently ongoing. The main framework of the new classification was presented to the WHA in May 2019 (41). Refinements of ICD-11 are led by the ICD-11 governance team and supported by the WHO-FIC networks comprising the reference groups and advisory committees of WHO. The Montpellier WHO CC CSS plays a special role in supporting the WHO through its academic and research projects. The data provided by these initiatives will be essential for fine-tuning improvements in the Allergic and hypersensitivity conditionssection of ICD. In fact, this section has been serving as a model for the refinement process, since it is the first time that many of these conditions have been represented together in a single location by means of the polyhierarchical design of ICD-11. Considering the fact that every change to the existing framework can have consequences not only for the allergy specialty but also for other specialties, all modifications have to be carefully and deeply considered and agreed with the concerned parts. Input mechanisms required demonstrated scientific evidence and consensus across all ICD stakeholders.

The outcomes of this engagement process have provided a snapshot view of how the international classifications are currently being used and of how we will be able to work together with WHO to assist adoption of the new A/H classification. For instance, those countries in which no classification system is used are being targeted for early adoption of ICD-11, and other countries using ICD-9 (or national adaptations) will be able to transfer directly to ICD-11. 
In this survey, we decided to include only the main terms and definitions in the new $\mathrm{A} / \mathrm{H}$ classification in order to simplify the task for our respondents and in the hope of thereby obtaining a higher response rate. For this reason many of the 49 responses to the open question of the survey were related to entities not mentioned in the proposed survey. However, all the comments have been taken into account, considering that ICD-11 is not intended to be a specialty classification but a system for use by a broad range of end-users.

Appropriate usage of codes for recording disorders is a key issue to prevent misclassification. The results of the current survey underline the need for increasing awareness of ICD-11 and its coding procedures as well as for educational programs to support ICD-11 end-users. These are two further goals of the Montpellier WHO CC.

Over recent decades the allergy community has been concerned to improve terminology and definitions in the field of allergy, as evidenced in many documents which have been published to date (44-74). The harmonization of $\mathrm{A} / \mathrm{H}$ terminology and definitions is critical for our community in today's globalized world with its international multicentre clinical trials and with the development of "personalized medicine". All the main published international consensuses and guidelines in the field of $\mathrm{A} / \mathrm{H}$ have been considered in the drafting of the ICD-11Allergic and hypersensitivity conditions classification in the ICD-11 chapter. The ICD-11 is recognized by the allergy community as the main official means to reach global harmonization in nomenclature and definitions to support the allergy community in the years to come. The allergy community recognizes the ICD-11 as a clinical tool and classification, in strong contrast to ICD-10 that designed for statistics only. This is an important finding of the survey which you should also highlight. Meanwhile, immunological disorders have been updated under the same chapter, including for example immunodeficiencies and rare diseases.

Many quality measures, such as those from US HealthGrades and the Agency for Healthcare Research and Quality, rely on the WHO ICD codes. Improving the specification of conditions will help clarify the connection between a provider's performance and the patient's condition. Accurate and updated diagnostic and procedure codes will improve data on the outcomes, efficacy, and costs of new medical technology and will facilitate fair reimbursement policies. It will help payers and providers to identify patients in need of disease management more easily and will more effectively tailor disease management programs (27).

By allowing all the relevant diagnostic terms for allergic and hypersensitivity conditions to be included in ICD-11, WHO has recognized their importance not only to clinicians but also to public health and those involved in studying and managing it, including epidemiologists, statisticians, health care planners and other stakeholders. Importantly, the new classification will enable the collection of more accurate epidemiological data to support quality management of patients with allergies and to better facilitate health care planning and decision-making, including public health measures to prevent and reduce the mortality and morbidity attributable to A/H. The improved ontological structure of ICD-11 and standardized terminology and definitions throughout the ICD-11 will also facilitate international comparisons of quality care and the sharing of best practice globally.

An important limitation of the survey is the differential response rate by regional area. We consider, however, that it is the quality of responses received rather than their quantity or their geographical representativeness that is most important. Although this did not affect our overall data analysis, it may highlight the need for allergy specialty development in the areas where the number of responders was low. Despite the specific response rate, the survey represented a unique opportunity to give voice to colleagues from 74 countries. In some countries, notably China, the most populous nation in the world, we received fewer responses than might have been expected. We hypothesise that recipients may not have been able to access the survey due to national regulations prohibiting Google ${ }^{\circledR}$ accounts. Other factors which may have influenced the response rate include the high number of questions for busy doctors and health professionals to answer, difficulty in accessing the online questionnaire and difficulties with the English language. Also it was not possible to have the initial sample size parameter since the survey has been disseminated by e-mail, social media and through national or regional allergy academies. 
We believe that, in addition to helping during the implementation phase of the new ICD-11 "Allergic and hypersensitivity conditions" classification, all the comments provided will help to improve the A/H classification and to increase awareness by different disciplines of what actions are needed to ensure more accurate epidemiological data and better clinical management of patients with allergic and hypersensitivity disorders. The efforts presented in this manuscript are aligned to additional ongoing national and international actions in order to ensure quality of allergy and hypersensitivity conditions data in the forthcoming years.

\section{ABREVIATIONS}

A/H: allergic and hypersensitivity conditions

AAAAI: American Academy of Allergy Asthma and Immunology

ACAAI: American College of Allergy Asthma and Immunology

AFRO: primarily sub-Saharan Africa

APAAACI: Asia Pacific Association of Allergy, Asthma and Clinical Immunology

EAACI: European Academy of Allergy and Clinical Immunology

EMRO: Eastern Mediterranean/North Africa

EURO: Europe

ICD: International Classification of Diseases

MMS: Mortality and morbidity statistics

PAHO: the Americas

SEARO: Southeast Asia

SLAAI: Latin American Society of Allergy, Asthma and Immunology

WAO: World Allergy Organization

WHA: World Heal Assembly

WHO: World Health Organization

WHO-FIC: World Health Organization - Family of International Classifications

WHO CC: World Health Organization Collaborating Centre

WPRO: Western Pacific

References

1. Cornet R, Chute CG. Health Concept and Knowledge Management: twenty-five Year of Evolution. Yearb Med Inform. 2016 Aug 2;Suppl 1:S32-41.

2. Demoly P, Tanno LK, Akdis CA, Lau S, Calderon MA, Santos AF, et al. Global classification and coding of hypersensitivity diseases - An EAACI - WAO survey, strategic paper and review. Allergy 2014; 69: 559-570.

3. World Heath Organization ICD-11 website (cited, available: https://www.who.int/classifications/icd/en/ accessed February 2020).

4. Knibbs GH. The International classification of disease and causes of death and its revision. Med J Aust $1929 ; 1: 2-12$.

5. Moriyama IM, Loy RM, Robb-Smith AHT. History of the statistical classification of diseases and causes of death. Rosenberg HM, Hoyert DL, eds. Hyattsville, MD: National Center for Health Statistics 2011.

6. National Academy on an Aging Society. Chronic Conditions: A challenge for the 21st Century. 2000. 
7. Centers for Disease Control. "CDC Fast Facts A-Z," Vital Health Statistics. 2003 [cited 28 Oct 2011]. http://www.cdc.gov/nchs/fastats/allergies.htm, http://www.aafa.org/display.cfm?id=9\&sub=30 (accessed 5 Sept 2011)

8. Center of Disease Control and Prevention (CDC) website. (cited, available: https://www.cdc.gov/nchs/fastats/health-expenditures.htm accessed February 2020)

9. Tanno LK, Calderon MA, Goldberg BJ, Akdis CA, Papadopoulos NG, Demoly P. Categorization of Allergic Disorders in the New World Health Organization International Classification of Diseases. Clin Transl Allergy 2014; 4: 42.

10. Tanno LK, Ganem F, Demoly P, Toscano CM, Bierrenbach AL. Undernotification of anaphylaxis deaths in Brazil due to difficult coding under the ICD-10. Allergy 2012; 67: 783-789.

11. Papadopoulos NG, Agache I, Bavbek S, Bilo BM, Braido F, Cardona V et al. Research needs in allergy: an EAACI position paper, in collaboration with EFA. Clin Transl Allergy 2012;2:21.

12. Pawankar R, Canonica GW, ST Holgate ST, Lockey RF, Blaiss M. The WAO White Book on Allergy (Update. 2013)

13. Tanno LK, Calderon MA, Smith HE, Sanchez-Borges M, Sheikh A, Demoly P; Joint Allergy Academies. Dissemination of definitions and concepts of allergic and hypersensitivity conditions. World Allergy Organ J. 2016; 9: 24.

14. World Health Organization, ICD-11 Beta Draft website. (cited, available: http://apps.who.int/classifications/icd11/browse/l-m/en January 2020).

15. Tanno LK, Casale T, Papadopoulos NG, Sanchez-Borges M, Thiens F, Pawankar R, Calderon MA, Gómez M, Sisul JC, Ansotegui IJ, Sublett J, Demoly P. A call to arms of specialty societies to review the WHO International Classification of Diseases, Eleventh Revision terms appropriate for the diseases they manage: The example of the Joint Allergy Academies. Allergy Asthma Proc. 2017 Jul 1;38(4):5455 .

16. Tanno LK, Calderon MA, Goldberg BJ, Gayraud J, Bircher AJ, Casale T et al. Constructing a classification of hypersensitivity/allergic diseases for ICD-11 by sourcing the allergist community. Allergy 2015; 70: 609-15.

17. Tanno LK, Calderon MA, Demoly P; on behalf the Joint Allergy Academies. New Allergic and Hypersensitivity Conditions Section in the International Classification of Diseases-11. Allergy Asthma Immunol Res 2016; 8: 383-8.

18. Tanno LK, Simons FE, Annesi-Maesano I, Calderon MA, Aymé S, Demoly P; Joint Allergy Academies. Fatal anaphylaxis registries data support changes in the who anaphylaxis mortality coding rules. Orphanet J Rare Dis 2017; 12: 8.

19. Tanno LK, Bierrenbach AL, Simons FER, Cardona V, Thong BY, Molinari N, Calderon MA, Worm M, Chang YS, Papadopoulos NG, Casale T, Demoly P; on behalf the Joint Allergy Academies. Critical view of anaphylaxis epidemiology: open questions and new perspectives. Allergy Asthma Clin Immunol 2018; 14: 12 .

20. Tanno LK, Calderon M, Papadopoulos NG, Demoly P. Mapping hypersensitivity/allergic diseases in the International Classification of Diseases (ICD)-11: cross-linking terms and unmet needs. Clin Transl Allergy 2015; 5: 20.

21. Tanno LK, Calderon MA, Demoly P; on behalf the Joint Allergy Academies. Making allergic and hypersensitivity conditions visible in the International Classification of Diseases-11. Asian Pac Allergy 2015; 5: 193-6.

22. Tanno LK, Calderon MA, Demoly P; on behalf the Joint Allergy Academies. Optimization and simplification of the allergic and hypersensitivity conditions classification for the ICD-11. Allergy 2016; 71: 671-6.

23. Tanno LK, Calderon MA, Papadopoulos NG, Sanchez-Borges M, Rosenwasser LJ, Bousquet J, et al. Revisiting Desensitization and Allergen Immunotherapy Concepts for the International Classification of Diseases (ICD)-11. J Allergy Clin Immunol Pract 2016; 4: 643-9.

24. Tanno LK, Calderon MA, Li J, Casale T, Demoly P. Updating Allergy/Hypersensitivity diagnostic procedures in the WHO ICD-11 revision. J Allergy Clin Immunol Pract 2016; 4: 650-7. 
25. Tanno LK, Calderon MA, Papadopoulos NG, Sanchez-Borges M, Moon HB, Sisul JC, Jares EJ, Sublett JL, Casale T, Demoly P; Joint Allergy Academies. Surveying the new allergic and hypersensitivity conditions chapter of the International classification of diseases (ICD)-11. Allergy 2016; 71: 1235-40.

26. Tanno LK, Calderon M, Demoly P; Joint Allergy Academies. Supporting the validation of the new allergic and hypersensitivity conditions section of the World Health Organization International Classification of Diseases-11. Asia Pac Allergy 2016; 6: 149-56.

27. Tanno LK, Calderon M, Sublett JL, Casale T, Demoly P; Joint Allergy Academies. Smoothing the transition from International Classification of Diseases, Tenth Revision, Clinical Modification to International Classification of Diseases, Eleventh Revision. J Allergy Clin Immunol Pract 2016; 4: 1265-7.

28. Tanno LK, Bierrenbach AL, Calderon MA, Sheikh A, Simons FE, Demoly P; Joint Allergy Academies. Decreasing the undernotification of anaphylaxis deaths in Brazil through the International Classification of Diseases (ICD)-11 revision. Allergy 2017; 72: 120-5.

29. Tanno LK, I Ansotegui, P Demoly. Globalization and anaphylaxis. Curr Opin Allergy Clin Immunol 2018; in press - doi: 10.1097/ACI.000000000000467

30. Tanno LK, Molinari N, Bruel S, Bourrain JL, Calderon M, Aubas P, Demoly P; Joint Allergy Academies. Field-testing the New Anaphylaxis' Classification for the WHO International Classification of Diseases (ICD)-11 Revision. Allergy. 2017 May;72(5):820-826. doi: 10.1111/all.13093.

31. Tanno LK, Sublett JL, Meadows JA, Calderon M, Gross GN, Casale T, Demoly P; Joint Allergy Academies. Perspectives of the International Classification of Diseases (ICD)-11 in Allergy Clinical Practice in the United States of America. Ann Allergy Asthma Immunol. 2017 Feb;118(2):127-132.

32. Tanno LK, Chalmers RJ, Calderon MA, Aymé S, Demoly P; on behalf the Joint Allergy Academies. Reaching multidisciplinary consensus on classification of anaphylaxis for the eleventh revision of the World Health Organization's (WHO) International Classification of Diseases (ICD-11). Orphanet J Rare Dis. 2017 Mar 16;12(1):53.

33. Tanno LK, Calderon MA, Linzer JFSr, Chalmers RJG, Demoly P, on behalf of the Joint Allergy Academies. Collaboration between specialties for respiratory allergies in the international classification of diseases (ICD)-11. Respiratory Research 2017, Feb 10;18(1):34.

34. Tanno LK, Haahtela T, Calderon MA, Cruz A, Demoly P; Joint Allergy Academies. Implementation gaps for asthma prevention and control. Respir Med. 2017 Sep;130:13-19.

35. Tanno LK, Torres MJ, Castells M, Demoly P; Joint Allergy Academies. What can we learn in drug allergy management from World Health Organization's International classifications? Allergy. 2018 May;73(5):987-992.

36. Tanno LK, Demoly P. Lessons of Drug Allergy Management Through the World Health Organization's International Classification of Diseases (ICD)-11. Curr Treatment Opin in Allergy, 2018 March 5 (1):5259.

37. Tanno LK, Demoly P, on behalf of the Joint Allergy Academies. How can the World Health Organization's International Classification of Diseases (ICD)-11 change the clinical management of anaphylaxis? Expert Rev Clin Immunol. 2018 Sep 11:1-4. doi: 10.1080/1744666X.2018.1520094.

38. Tanno LK, Demoly P; Joint Allergy Academies. Are outcome measures in allergic diseases relevant for the WHO's International Classification of Diseases in allergology? Curr Opin Allergy Clin Immunol. 2019 Jun;19(3):198-203.

39. Tanno LK, Chalmers R, Bierrenbach AL, Simons FER, Molinari N, Annesi-Maesano et al. on behalf Joint Allergy Academies. Changing the history of anaphylaxis mortality statistics througth the World Health Organization's International Classification of Diseases (ICD)-11. J Allergy Clin Immunol. 2019 Sep;144(3):627-633.

40. Demoly P, Tanno LK. Le modèle de l'anaphylaxie : une nouvelle version de la Classification Internationale des Maladies de l'Organisation Mondiale de la Santé pour 2019. Bulletin de l'Académie nationale de médecine 2020, in press

41. The Lancet. ICD-11. Lancet. 2019 Jun 8;393(10188):2275.

42. World Health Organization, Collaborating Centres list website. (cited, available: $\quad$ http://apps.who.int/whocc/Detail.aspx?cc_ref=FRA-133\&designation_da- 
te $1=1 / 6 / 2018 \&$ designation_date $2=18 / 7 / 2018 \&$ December 2019)

43. World Health Organization, MSAC website. (cited, available: https://www.who.int/classifications/icd/revision/en/ December 2019)

44. Johansson SG, Bieber T, Dahl R, et al. Revised nomenclature for allergy for global use: Report of the Nomenclature Review Committee of the World Allergy Organization, October 2003. J Allergy Clin Imunnol 2004; 113: 832-6.

45. The European Academy of Allergy and Clinical Immunology (EAACI). A European Declaration on Allergen Immunotherapy. Available at http://www.eaaci.org/resources/immunotherapy- declaration.html

46. Demoly P, Adkinson NF, Brockow K, Castells M, Chiriac AM, Greenberger PA, Khan DA, Lang DM, Park H-S, Pichler W, Sanchez-Borges M, Shiohara T, Thong BY-H. International Consensus on drug allergy. Allergy 2014; 69: 420-437.

47. Sampson HA, Munoz-Furlong A, Campbell RL, Adkinson NF Jr, Bock SA, Branum A et al. Second symposium on the definition and management of anaphylaxis: summary report - Second National Institute of Allergy and Infectious Disease/Food Allergy and Anaphylaxis Network Symposium. J Allergy Clin Immunol 2006;117:391- 397.

48. Scadding G, Hellings P, Alobid I, Bachert C, et al., Diagnostic tools in Rhinology EAACI position paper. Clinical and Translational Allergy 201110;1(1):2.

49. Fokkens W, Lund V, Mullol J; European Position Paper on Rhinosinusitis and Nasal Polyps. Rhinol Suppl 2007;(20):1-136.

50. Bousquet J, Schu nemann HJ, Zuberbier T, Bachert C, Baena-Cagnani CE, Bousquet PJ, et al. In collaboration with the WHO Collaborating Center of Asthma and Rhinitis (Montpellier). Development and implementation of guide- lines in allergic rhinitis - an ARIA-GA2LEN paper. Allergy 2010; 65: 1212-1221.

51. L. B. Bacharier, A. Boner, K.-H. Carlsen, P. A. Eigenmann, T. Frischer, M. Gctz et al. Diagnosis and treatment of asthma in childhood: a PRACTALL consensus report. Allergy 2008: 63: 5-34.

52. Asthma. Quick asthma facts \& The Faces of asthma [Internet]. Geneva: World Health Organization; 2010. Available from: http://www.who.int/respiratory/asthma/en/.

53. Matthew Masoli, Denise Fabian, Shaun Holt, Richard Beasley for the Global Initiative for Asthma (GINA) Program. The global burden of asthma: executive summary of the GINA. Dissemination Committee Report. Allergy 2004: 59: 469-478.

54. Bateman ED, Bousquet J, Keech ML, Busse WW, Clark TJ, Pedersen SE.The correlation between asthma control and health status: the GOAL study. Eur Respir J 2007; 29: 56-62.

55. Papadopoulos NG, Arakawa H, Carlsen K-H, Custovic A, Gern J, Lemanske R, et al.. International consensus on (icon) pediatric asthma. Allergy 2012; 67: 976-997.

56. Burks AW, Tang M, Sicherer S, Muraro A, Eigenmann PA, Ebisawa M, Fiocchi A, Chiang W, Beyer K, Wood R, Hourihane J, Jones SM, Lack G, Sampson HA. International consensus on (ICON) Food Allergy. J Allergy Clin Immunol 2012; 129: 906-920.

57. Simons FE, Ardusso LR, Bilò MB, Cardona V, Ebisawa M, El-Gamal YM, et al. International consensus on (ICON) Anaphylaxis. World Allergy Organ J 2014 30;7: 9.

58. Moscato G, Pala G, Cullinan P, Folletti I, Gerth van Wijk R, Pignatti P et al. EAACI Position Paper on assessment of cough in the workplace. Allergy 2014;69: 292-304.

59. Leonardi A, Bogacka E, Fauquert J-L, Kowalski ML, Groblewska A, Jedrzejczak-Czechowicz M, et al. Ocular allergy: recognizing and diagnosing hypersensitivity disorders of the ocular surface. Allergy 2012; 67: 1327-1337.

60. La Rosa M, Lionetti E, Reibaldi M, Russo A, Longo A, Leonardi S, et al. Allergic conjunctivitis: a comprehensive review of the literature. Italian J Pediatrics 2013, 39:18.

61. Bonini S, Coassin M, Aronni S, Lambiase A. Vernal keratoconjunctivitis. Eye 2004; 18: 345-351.

62. Akdis CA, Akdis M, Bieber T, Bindslev-Jensen C, Boguniewicz M, Eigenmann PA, et al. Diagnosis and treatment of atopic dermatitis in children and adults: European Academy of Allergology and Clinical Immunology/American Academy of Allergy, Asthma and Immunology/PRACTALL Consensus Report. Allergy 2006: 61: 969-987. 
63. Bonitsis NG, Tatsioni A, Bassioukas K, Ioannidis JP.Allergens responsible for allergic contact dermatitis among children: a systematic review and meta-analysis. Contact Dermatitis 2011;64: 245-57.

64. Tan CH, Rasool S, Johnston GA.Contact dermatitis: allergic and irritant. Clin Dermatol 2014;32:11624.

65. Cicardi M, Bork K, Caballero T, Craig T, Li HH, Longhurst H,et al. Evidence-based recommendations for the therapeutic management of angioedema owing to hereditary $\mathrm{C} 1$ inhibitor deficiency: consensus report of an International Working Group. Allergy. 2012;67: 147-57.

66. Craig T, Aygoren Pursun E, Bork K, Bowen T, Boysen H, Farkas H, et al. WAO Guideline for the Management of Hereditary Angioedema. WAO J 2012; 5: 182-199.

67. Soares-Weiser K, Panesar SS, Rader T, Takwoingi Y, Werfel T, Muraro A, et al. The diagnosis of food allergy: protocol for a systematic review. Clin Transl Allergy 2013, 3:18.

68. Bircher A, Scherer K. Delayed cutaneous manifestations of drug hypersensitivity.Med Clin North Am. 2010;94:711-25.

69. Pirmohamed M, Friedmann PS, Molokhia M, Loke YK, Smith C, Phillips E, La Grenade L, Carleton B, Papaluca-Amati M, Demoly P, Shear NH.Phenotype standardization for immune-mediated druginduced skin injury. Clin Pharmacol Ther 2011;89:896-901.

70. Roujeau JC. Clinical heterogeneity of drug hypersensitivity. Toxicology 2005; 15;209:123-129.

71. Biló BM, Rueff F, Mosbech H, Bonifazi F, Oude-Elberink JN; EAACI Interest Group on Insect Venom Hypersensitivity.Diagnosis of Hymenoptera venom allergy.Allergy. 2005;60:1339-1349.

72. Bonifazi F, Jutel M, Biló BM, Birnbaum J, Muller U; EAACI Interest Group on Insect Venom Hypersensitivity.Prevention and treatment of hymenoptera venom allergy: guidelines for clinical practice. Allergy 2005;60: 1459-1470.

73. Time to revisit the definition and clinical criteria for anaphylaxis? Turner PJ, Worm M, Ansotegui IJ, El-Gamal Y, Rivas MF, Fineman S, Geller M, Gonzalez-Estrada A, Greenberger PA, Tanno LK, Borges MS, Senna G, Sheikh A, Thong BY, Ebisawa M, Cardona V; WAO Anaphylaxis Committee. World Allergy Organ J. 2019 Oct 31;12(10):100066.

74. Zuberbier T, Aberer W, Asero R, Abdul Latiff AH, Baker D, Ballmer-Weber B, et al. The EAA$\mathrm{CI} / \mathrm{GA}^{2} \mathrm{LEN} / \mathrm{EDF} / \mathrm{WAO}$ guideline for the definition, classification, diagnosis and management of urticaria. Allergy. 2018 Jul;73(7):1393-1414.

\section{FUNDING:}

Pascal Demoly and Luciana Kase Tanno received an unrestricted Novartis and MEDA/Mylan Pharma grants through CHUM administration. LKT received a research AllerGOS grant.

\section{CONFLICT OF INTERESTS:}

The authors declare that they do not have conflict of interests related to the contents of this article.

\section{CONTRIBUTIONS:}

The first and last authors contributed to the construction of the document (designed the study, including the questionnaire, analysed and interpreted the data, and wrote the manuscript). All the authors critically revised and approved the final version of the manuscript and agree to be accountable for all the aspects of the work.

\section{AKNOWLEDGEMENTS:}

We are grateful to all the representatives of the ICD-11 revision with whom we have been carrying on fruitful discussions, helping us to tune the here presented classification: Robert Jakob, Linda Best, Nenad Kostanjsek, Linda Moskal, Robert J G Chalmers, Jeffrey Linzer, Linda Edwards, Ségolène Ayme, Bertrand Bellet, Rodney Franklin, Matthew Helbert, August Colenbrander, Satoshi Kashii, Paulo E. C. Dantas, Christine Graham, Ashley Behrens, Julie Rust, Megan Cumerlato, Tsutomu Suzuki, Mitsuko Kondo, Hajime Takizawa, Nobuoki Kohno, Soichiro Miura, Nan Tajima and Toshio Ogawa. 
We would like to thank very much the national and international academies, and colleagues who supported the dissemination of the online survey. We are grateful for the participants for their responses.

\section{LIST OF TABLES}

Table 1: Responder to the international survey, response rates, demographic characteristics, and classification in use

Table 2: Responses to open ended questions from a web international survey fielded in 2019: what is expected by a classification system and what the ICD-11 is able to bring

\section{LIST OF FIGURES}

Figure 1: Representation of the participants to the international survey per world region

Figure 2: The main purpose for a classification system according to the allergy community and analysis per region

Figure 3: Outcomes of the engaging opinion process: scoring the accuracy of the ICD-11 Allergic and hypersensitivity conditions section

Annex 1: Questionnaire "GLOBAL IMPLEMENTATION OF THE WORLD HEALTH ORGANIZATION'S INTERNATIONAL CLASSIFICATION OF DISEASES (ICD)-11: THE ALLERGIC AND HYPERSENSITIVITY CONDITIONS MODEL".

\section{Hosted file}

image1.emf available at https://authorea.com/users/323350/articles/452072-globalimplementation-of-the-world-health-organization-s-international-classification-ofdiseases-icd-11-the-allergic-and-hypersensitivity-conditions-model

Figure 2: Representation of the participants to the international survey per world region

\section{Hosted file}

image2.emf available at https://authorea.com/users/323350/articles/452072-globalimplementation-of-the-world-health-organization-s-international-classification-ofdiseases-icd-11-the-allergic-and-hypersensitivity-conditions-model

Figure 2: The main purpose for a classification system according to the allergy community and analysis per region

\section{Hosted file}

image3.emf available at https://authorea.com/users/323350/articles/452072-globalimplementation-of-the-world-health-organization-s-international-classification-ofdiseases-icd-11-the-allergic-and-hypersensitivity-conditions-model

Figure 3: Outcomes of the engaging opinion process: scoring the accuracy of the ICD-11 Allergic and hypersensitivity conditions section

Table 1: Responders to the international survey, response rates, demographic characteristics, and classification in use 


\begin{tabular}{|c|c|c|c|c|c|c|c|c|c|c|}
\hline $\begin{array}{l}\text { WHO } \\
\text { Global } \\
\text { Re- } \\
\text { gion }\end{array}$ & $\begin{array}{l}\text { Country } \\
(\mathrm{N} \\
\text { re- } \\
\text { sponses) }\end{array}$ & $\begin{array}{l}\text { Total } \\
\mathrm{N}^{\mathrm{O}} \\
\text { re- } \\
\text { sponses }\end{array}$ & $\begin{array}{l}\text { Mean } \\
\text { age } \\
\text { (years) }\end{array}$ & $\begin{array}{l}\text { Ratio } \\
\text { women/ }\end{array}$ & $\begin{array}{l}\text { Specialty } \\
\mathbf{n}\left(\mathbb{R}^{\prime}\right)\end{array}$ & $\begin{array}{l}\text { More } \\
\text { than } \\
20 \\
\text { years } \\
\text { of } \\
\text { pro- } \\
\text { fes- } \\
\text { sional } \\
\text { expe- } \\
\text { ri- } \\
\text { ence } \\
\text { (\%) }\end{array}$ & $\begin{array}{l}\% \\
\text { spend- } \\
\text { ing } \\
\text { more } \\
\text { than } \\
20 \\
\text { hours/ } \\
\text { week } \\
\text { with } \\
\text { aller- } \\
\text { gic } \\
\text { dis- } \\
\text { eases }\end{array}$ & $\begin{array}{l}\text { Work } \\
\text { set- } \\
\text { ting } \\
(\%)\end{array}$ & $\begin{array}{l}\text { In } \\
\text { your } \\
\text { prac- } \\
\text { tice, } \\
\text { who } \\
\text { codes } \\
\text { dis- } \\
\text { eases / } \\
\text { inter- } \\
\text { ven- } \\
\text { tions? }\end{array}$ & $\begin{array}{l}\text { Classifica } \\
\text { cod- } \\
\text { ing } \\
\text { tool } \\
\text { used } \\
\text { in } \\
\text { the } \\
\text { day- } \\
\text { to- } \\
\text { day } \\
\text { clini- } \\
\text { cal } \\
\text { work } \\
\text { (\%) }\end{array}$ \\
\hline AFRO & $\begin{array}{l}\text { Algeria } \\
(2) \\
\text { Kenya } \\
(1) \\
\text { Nigeria } \\
(1) \\
\text { South } \\
\text { Africa } \\
(2) \text { Zim- } \\
\text { babwe } \\
(1)\end{array}$ & 7 & 49.5 & 0.16 & $\begin{array}{l}\text { Allergist } \\
(29) \\
\text { Clinical } \\
\text { Immu- } \\
\text { nologist } \\
(14.2) \\
\text { Pulmo- } \\
\text { nologist } \\
(14.2) \\
\text { Paedia- } \\
\text { trician } \\
(14.2) \\
\text { Re- } \\
\text { searcher } \\
(14.2) \\
\text { Other } \\
(14.2)\end{array}$ & 57.1 & 57.1 & $\begin{array}{l}\text { Private } \\
(28.6) \\
\text { Public } \\
(42.8) \\
\text { Both } \\
(28.6)\end{array}$ & $\begin{array}{l}\text { Yourself } \\
(43.0) \text { A } \\
\text { staff } \\
\text { mem- } \\
\text { ber/ } \\
\text { institu- } \\
\text { tion } \\
(14.0) \\
\text { Nobody } \\
(43.0) \text { I } \\
\text { don't } \\
\text { know } \\
(0.0)\end{array}$ & $\begin{array}{l}\text { ICD-10 } \\
(+ \\
\text { adapta- } \\
\text { tion) } \\
(57.1) \\
\text { ICD-9 } \\
(+ \\
\text { adapta- } \\
\text { tion) } \\
(14.3) \\
\text { SNOMED- } \\
\text { CT } \\
(0.0) \\
\text { Read } \\
\text { Codes } \\
(14.3) \\
\text { None } \\
(14.3) \\
\text { Other } \\
(0.0)\end{array}$ \\
\hline
\end{tabular}




\begin{tabular}{|c|c|c|c|c|c|c|c|c|c|c|}
\hline $\begin{array}{l}\text { WHO } \\
\text { Global } \\
\text { Re- } \\
\text { gion }\end{array}$ & $\begin{array}{l}\text { Country } \\
(\mathrm{N} \\
\text { re- } \\
\text { sponses) }\end{array}$ & $\begin{array}{l}\text { Total } \\
\mathrm{N}^{\mathrm{O}} \\
\text { re- } \\
\text { sponses }\end{array}$ & $\begin{array}{l}\text { Mean } \\
\text { age } \\
\text { (years) }\end{array}$ & $\begin{array}{l}\text { Ratio } \\
\text { women/n }\end{array}$ & $\begin{array}{l}\text { Specialty } \\
\mathrm{n}\left(\mathrm{A}^{\prime}\right)\end{array}$ & $\begin{array}{l}\text { More } \\
\text { than } \\
20 \\
\text { years } \\
\text { of } \\
\text { pro- } \\
\text { fes- } \\
\text { sional } \\
\text { expe- } \\
\text { ri- } \\
\text { ence } \\
(\%)\end{array}$ & $\begin{array}{l}\% \\
\text { spend- } \\
\text { ing } \\
\text { more } \\
\text { than } \\
20 \\
\text { hours/ } \\
\text { week } \\
\text { with } \\
\text { aller- } \\
\text { gic } \\
\text { dis- } \\
\text { eases }\end{array}$ & $\begin{array}{l}\text { Work } \\
\text { set- } \\
\text { ting } \\
(\%)\end{array}$ & $\begin{array}{l}\text { In } \\
\text { your } \\
\text { prac- } \\
\text { tice, } \\
\text { who } \\
\text { codes } \\
\text { dis- } \\
\text { eases/ } \\
\text { inter- } \\
\text { ven- } \\
\text { tions? }\end{array}$ & $\begin{array}{l}\text { Classifica } \\
\text { cod- } \\
\text { ing } \\
\text { tool } \\
\text { used } \\
\text { in } \\
\text { the } \\
\text { day- } \\
\text { to- } \\
\text { day } \\
\text { clini- } \\
\text { cal } \\
\text { work } \\
\text { (\%) }\end{array}$ \\
\hline PARO & $\begin{array}{l}\text { Argentina } \\
(15) \\
\text { Brazil } \\
(30) \\
\text { Canada } \\
(8) \\
\text { Chile } \\
(5) \\
\text { Colom- } \\
\text { bia (6) } \\
\text { Costa } \\
\text { Rica (3) } \\
\text { Cuba } \\
(2) \text { Do- } \\
\text { minican } \\
\text { Repub- } \\
\text { lic (4) } \\
\text { Ecuador } \\
(3) \text { Hon- } \\
\text { duras } \\
(2) \\
\text { Mexico } \\
\text { (16) } \\
\text { Nicaragua } \\
(1) \\
\text { Panama } \\
(1) \\
\text { Paraguay } \\
(4) \text { Peru } \\
(1) \\
\text { United } \\
\text { States } \\
\text { of } \\
\text { America } \\
(39) \\
\text { Venezuela } \\
(1) \\
\text { (1) }\end{array}$ & 141 & 55.2 & 0.83 & $\begin{array}{l}\text { Allergist } \\
(81.5) \\
\text { Clinical } \\
\text { Immu- } \\
\text { nologist } \\
(9.2) \\
\text { Derma- } \\
\text { tologist } \\
(1.4) \\
\text { ENT } \\
(1.4) \\
\text { Paedia- } \\
\text { trician } \\
(4.2) \\
\text { Re- } \\
\text { searcher } \\
(1.4) \\
\text { Other } \\
(0.9)\end{array}$ & 51.7 & 74.5 & $\begin{array}{l}\text { Private } \\
(49.0) \\
\text { Public } \\
(18.4) \\
\text { Both } \\
(32.6)\end{array}$ & $\begin{array}{l}\text { Yourself } \\
(68.8) \text { A } \\
\text { staff } \\
\text { member } \\
\text { / insti- } \\
\text { tution } \\
(18.0) \\
\text { Nobody } \\
(9.2) \text { I } \\
\text { don't } \\
\text { know } \\
(4.2)\end{array}$ & $\begin{array}{l}\text { ICD-10 } \\
(+ \\
\text { adapta- } \\
\text { tion) } \\
(69.5) \\
\text { ICD-9 } \\
(+ \\
\text { adapta- } \\
\text { tion) } \\
(7.0) \\
\text { SNOMED } \\
\text { CT } \\
(0.7) \\
\text { Read } \\
\text { Codes } \\
(3.5) \\
\text { None } \\
(17.0) \\
\text { Other } \\
(2.3)\end{array}$ \\
\hline
\end{tabular}




\begin{tabular}{|c|c|c|c|c|c|c|c|c|c|c|}
\hline $\begin{array}{l}\text { WHO } \\
\text { Global } \\
\text { Re- } \\
\text { gion }\end{array}$ & $\begin{array}{l}\text { Country } \\
(\mathrm{N} \\
\text { re- } \\
\text { sponses) }\end{array}$ & $\begin{array}{l}\text { Total } \\
\mathrm{N}^{\mathrm{O}} \\
\text { re- } \\
\text { sponses }\end{array}$ & $\begin{array}{l}\text { Mean } \\
\text { age } \\
\text { (years) }\end{array}$ & $\begin{array}{l}\text { Ratio } \\
\text { women/r }\end{array}$ & $\begin{array}{l}\text { Specialty } \\
\mathrm{n}\left(\mathrm{C}^{\mathrm{K}}\right)\end{array}$ & $\begin{array}{l}\text { More } \\
\text { than } \\
20 \\
\text { years } \\
\text { of } \\
\text { pro- } \\
\text { fes- } \\
\text { sional } \\
\text { expe- } \\
\text { ri- } \\
\text { ence } \\
\text { (\%) }\end{array}$ & $\begin{array}{l}\% \\
\text { spend- } \\
\text { ing } \\
\text { more } \\
\text { than } \\
20 \\
\text { hours / } \\
\text { week } \\
\text { with } \\
\text { aller- } \\
\text { gic } \\
\text { dis- } \\
\text { eases }\end{array}$ & $\begin{array}{l}\text { Work } \\
\text { set- } \\
\text { ting } \\
(\%)\end{array}$ & $\begin{array}{l}\text { In } \\
\text { your } \\
\text { prac- } \\
\text { tice, } \\
\text { who } \\
\text { codes } \\
\text { dis- } \\
\text { eases/ } \\
\text { inter- } \\
\text { ven- } \\
\text { tions? }\end{array}$ & $\begin{array}{l}\text { Classifica } \\
\text { cod- } \\
\text { ing } \\
\text { tool } \\
\text { used } \\
\text { in } \\
\text { the } \\
\text { day- } \\
\text { to- } \\
\text { day } \\
\text { clini- } \\
\text { cal } \\
\text { work } \\
\text { (\%) }\end{array}$ \\
\hline EMRO & $\begin{array}{l}\text { Egypt } \\
(6) \text { Iran } \\
(1) \\
\text { Jordan } \\
(1) \\
\text { Lebanon } \\
(3) \\
\text { Morocco } \\
(1) \text { Pak- } \\
\text { istan (3) } \\
\text { Saudi } \\
\text { Arabia } \\
(2) \\
\text { Tunisia } \\
(1)\end{array}$ & 18 & 49.3 & 0.80 & $\begin{array}{l}\text { Allergist } \\
(50) \\
\text { Clinical } \\
\text { Immu- } \\
\text { nologist } \\
(5.5) \\
\text { Paedia- } \\
\text { trician } \\
(22.5) \\
\text { Primary } \\
\text { care } \\
(5.5) \\
\text { Pulmo- } \\
\text { nologist } \\
(5.5) \\
\text { Re- } \\
\text { searcher } \\
(5.5) \\
\text { Other } \\
(5.5)\end{array}$ & 38.9 & 44.5 & $\begin{array}{l}\text { Private } \\
(33.3) \\
\text { Public } \\
(33.3) \\
\text { Both } \\
(33.4)\end{array}$ & $\begin{array}{l}\text { Yourself } \\
(50) \text { A } \\
\text { staff } \\
\text { member } \\
\text { / insti- } \\
\text { tution } \\
(11.1) \\
\text { Nobody } \\
(33.3) \text { I } \\
\text { don't } \\
\text { know } \\
(4.7)\end{array}$ & $\begin{array}{l}\text { ICD-10 } \\
(+ \\
\text { adapta- } \\
\text { tion }) \\
(22.2) \\
\text { ICD-9 } \\
(+ \\
\text { adapta- } \\
\text { tion) } \\
(0.0) \\
\text { SNOMED- } \\
\text { CT } \\
(0.0) \\
\text { Read } \\
\text { Codes } \\
\text { (5.6) } \\
\text { None } \\
\text { (72.2) } \\
\text { Other } \\
(0.0)\end{array}$ \\
\hline
\end{tabular}




\begin{tabular}{|c|c|c|c|c|c|c|c|c|c|c|}
\hline $\begin{array}{l}\text { WHO } \\
\text { Global } \\
\text { Re- } \\
\text { gion }\end{array}$ & $\begin{array}{l}\text { Country } \\
(\mathrm{N} \\
\text { re- } \\
\text { sponses) }\end{array}$ & $\begin{array}{l}\text { Total } \\
\mathrm{N}^{\mathrm{O}} \\
\text { re- } \\
\text { sponses }\end{array}$ & $\begin{array}{l}\text { Mean } \\
\text { age } \\
\text { (years) }\end{array}$ & $\begin{array}{l}\text { Ratio } \\
\text { women/ }\end{array}$ & $\begin{array}{l}\text { Specialty } \\
\text { ( }\left(9 \mathbb{K}^{\prime}\right)\end{array}$ & $\begin{array}{l}\text { More } \\
\text { than } \\
20 \\
\text { years } \\
\text { of } \\
\text { pro- } \\
\text { fes- } \\
\text { sional } \\
\text { expe- } \\
\text { ri- } \\
\text { ence } \\
\text { (\%) }\end{array}$ & $\begin{array}{l}\% \\
\text { spend- } \\
\text { ing } \\
\text { more } \\
\text { than } \\
20 \\
\text { hours/ } \\
\text { week } \\
\text { with } \\
\text { aller- } \\
\text { gic } \\
\text { dis- } \\
\text { eases }\end{array}$ & $\begin{array}{l}\text { Work } \\
\text { set- } \\
\text { ting } \\
(\%)\end{array}$ & $\begin{array}{l}\text { In } \\
\text { your } \\
\text { prac- } \\
\text { tice, } \\
\text { who } \\
\text { codes } \\
\text { dis- } \\
\text { eases / } \\
\text { inter- } \\
\text { ven- } \\
\text { tions? }\end{array}$ & $\begin{array}{l}\text { Classifica } \\
\text { cod- } \\
\text { ing } \\
\text { tool } \\
\text { used } \\
\text { in } \\
\text { the } \\
\text { day- } \\
\text { to- } \\
\text { day } \\
\text { clini- } \\
\text { cal } \\
\text { work } \\
\text { (\%) }\end{array}$ \\
\hline EURO & $\begin{array}{l}\text { Albania } \\
(1) \\
\text { Armenia } \\
(2) \\
\text { Austria } \\
(6) \\
\text { Belarus } \\
(1) \\
\text { Belgium } \\
(7) \\
\text { Bulgaria } \\
(5) \\
\text { Croatia } \\
(5) \\
\text { Czech } \\
\text { Repub- } \\
\text { lic (2) } \\
\text { Den- } \\
\text { mark } \\
(1) \\
\text { Finland } \\
(1) \\
\text { France } \\
(20) \\
\text { Georgia } \\
(2) \text { Ger- } \\
\text { many } \\
(5) \\
\text { Greece } \\
(11) \\
\text { Hun- } \\
\text { gary (1) } \\
\text { Israel } \\
(3) \text { Italy } \\
(20) \\
\text { Lithua- } \\
\text { nia }(2) \\
\text { (5) }\end{array}$ & 189 & 48.7 & 1.07 & $\begin{array}{l}\text { Allergist } \\
(69.8) \\
\text { Clinical } \\
\text { Immu- } \\
\text { nologist } \\
(4.2) \\
\text { Derma- } \\
\text { tologist } \\
(6.3) \\
\text { ENT } \\
(0.5) \\
\text { Paedia- } \\
\text { trician } \\
(11.0) \\
\text { Primary } \\
\text { care } \\
(1.0) \\
\text { Pulmo- } \\
\text { nologist } \\
(5.2) \\
\text { Re- } \\
\text { searcher } \\
(1.0) \\
\text { Other } \\
(1.0)\end{array}$ & 46.5 & 68.8 & $\begin{array}{l}\text { Private } \\
(14.3) \\
\text { Public } \\
(51.3) \\
\text { Both } \\
(34.4)\end{array}$ & $\begin{array}{l}\text { Yourself } \\
(53.0) \text { A } \\
\text { staff } \\
\text { member } \\
\text { / insti- } \\
\text { tution } \\
(30.1) \\
\text { Nobody } \\
(10.0) \text { I } \\
\text { don't } \\
\text { know } \\
(6.9)\end{array}$ & $\begin{array}{l}\text { ICD-10 } \\
(+ \\
\text { adapta- } \\
\text { tion }) \\
(72.0) \\
\text { ICD-9 } \\
(+ \\
\text { adapta- } \\
\text { tion) } \\
(0.5) \\
\text { SNOMED- } \\
\text { CT } \\
(1.0) \\
\text { Read } \\
\text { Codes } \\
(1.6) \\
\text { None } \\
\text { (19.6) } \\
\text { Other } \\
\text { (5.3) }\end{array}$ \\
\hline
\end{tabular}




\begin{tabular}{|c|c|c|c|c|c|c|c|c|c|c|}
\hline $\begin{array}{l}\text { WHO } \\
\text { Global } \\
\text { Re- } \\
\text { gion }\end{array}$ & $\begin{array}{l}\text { Country } \\
(\mathrm{N} \\
\text { re- } \\
\text { sponses) }\end{array}$ & $\begin{array}{l}\text { Total } \\
\mathrm{N}^{\mathrm{O}} \\
\text { re- } \\
\text { sponses }\end{array}$ & $\begin{array}{l}\text { Mean } \\
\text { age } \\
\text { (years) }\end{array}$ & $\begin{array}{l}\text { Ratio } \\
\text { women/1 }\end{array}$ & $\begin{array}{l}\text { Specialty } \\
\text { n(R) }\end{array}$ & $\begin{array}{l}\text { More } \\
\text { than } \\
20 \\
\text { years } \\
\text { of } \\
\text { pro- } \\
\text { fes- } \\
\text { sional } \\
\text { expe- } \\
\text { ri- } \\
\text { ence } \\
(\%)\end{array}$ & $\begin{array}{l}\% \\
\text { spend- } \\
\text { ing } \\
\text { more } \\
\text { than } \\
20 \\
\text { hours/ } \\
\text { week } \\
\text { with } \\
\text { aller- } \\
\text { gic } \\
\text { dis- } \\
\text { eases }\end{array}$ & $\begin{array}{l}\text { Work } \\
\text { set- } \\
\text { ting } \\
(\%)\end{array}$ & $\begin{array}{l}\text { In } \\
\text { your } \\
\text { prac- } \\
\text { tice, } \\
\text { who } \\
\text { codes } \\
\text { dis- } \\
\text { eases / } \\
\text { inter- } \\
\text { ven- } \\
\text { tions? }\end{array}$ & $\begin{array}{l}\text { Classifica } \\
\text { cod- } \\
\text { ing } \\
\text { tool } \\
\text { used } \\
\text { in } \\
\text { the } \\
\text { day- } \\
\text { to- } \\
\text { day } \\
\text { clini- } \\
\text { cal } \\
\text { work } \\
\text { (\%) }\end{array}$ \\
\hline SEARO & $\begin{array}{l}\text { India } \\
\text { (5) In- } \\
\text { donesia } \\
\text { (2) Sri } \\
\text { Lanka } \\
(2) \\
\text { Thai- } \\
\text { land } \\
(10)\end{array}$ & 19 & 41.4 & 1.37 & $\begin{array}{l}\text { Allergist } \\
(73.7) \\
\text { Clinical } \\
\text { Immu- } \\
\text { nologist } \\
(5.2) \\
\text { Paedia- } \\
\text { trician } \\
(10.5) \\
\text { Pulmo- } \\
\text { nologist } \\
(5.2) \\
\text { Re- } \\
\text { searcher } \\
(5.2)\end{array}$ & 21.0 & 31.6 & $\begin{array}{l}\text { Private } \\
(15.8) \\
\text { Public } \\
(21.0) \\
\text { Both } \\
(63.2)\end{array}$ & $\begin{array}{l}\text { Yourself } \\
(47.3) \text { A } \\
\text { staff } \\
\text { member } \\
\text { / insti- } \\
\text { tution } \\
(26.3) \\
\text { Nobody } \\
(21.0) \text { I } \\
\text { don't } \\
\text { know } \\
(5.4)\end{array}$ & $\begin{array}{l}\text { ICD-10 } \\
(+ \\
\text { adapta- } \\
\text { tion }) \\
(73.7) \\
\text { ICD-9 } \\
(+ \\
\text { adapta- } \\
\text { tion) } \\
(0.0) \\
\text { SNOMED- } \\
\text { CT } \\
(0.0) \\
\text { Read } \\
\text { Codes } \\
(0.0) \\
\text { None } \\
(21.0) \\
\text { Other } \\
(5.3)\end{array}$ \\
\hline
\end{tabular}




\begin{tabular}{|c|c|c|c|c|c|c|c|c|c|c|}
\hline $\begin{array}{l}\text { WHO } \\
\text { Global } \\
\text { Re- } \\
\text { gion }\end{array}$ & $\begin{array}{l}\text { Country } \\
(\mathrm{N} \\
\text { re- } \\
\text { sponses })\end{array}$ & $\begin{array}{l}\text { Total } \\
\mathrm{N}^{\mathrm{O}} \\
\text { re- } \\
\text { sponses }\end{array}$ & $\begin{array}{l}\text { Mean } \\
\text { age } \\
\text { (years) }\end{array}$ & $\begin{array}{l}\text { Ratio } \\
\text { women }\end{array}$ & $\begin{array}{l}\text { Specialty } \\
\text { m(QT) }\end{array}$ & $\begin{array}{l}\text { More } \\
\text { than } \\
20 \\
\text { years } \\
\text { of } \\
\text { pro- } \\
\text { fes- } \\
\text { sional } \\
\text { expe- } \\
\text { ri- } \\
\text { ence } \\
(\%) \\
\end{array}$ & $\begin{array}{l}\% \\
\text { spend- } \\
\text { ing } \\
\text { more } \\
\text { than } \\
20 \\
\text { hours/ } \\
\text { week } \\
\text { with } \\
\text { aller- } \\
\text { gic } \\
\text { dis- } \\
\text { eases }\end{array}$ & $\begin{array}{l}\text { Work } \\
\text { set- } \\
\text { ting } \\
(\%) \\
\end{array}$ & $\begin{array}{l}\text { In } \\
\text { your } \\
\text { prac- } \\
\text { tice, } \\
\text { who } \\
\text { codes } \\
\text { dis- } \\
\text { eases/ } \\
\text { inter- } \\
\text { ven- } \\
\text { tions? }\end{array}$ & $\begin{array}{l}\text { Classifica } \\
\text { cod- } \\
\text { ing } \\
\text { tool } \\
\text { used } \\
\text { in } \\
\text { the } \\
\text { day- } \\
\text { to- } \\
\text { day } \\
\text { clini- } \\
\text { cal } \\
\text { work } \\
(\%) \\
\end{array}$ \\
\hline WPRO & $\begin{array}{l}\text { Australia } \\
(14) \\
\text { Brunei } \\
\text { Darus- } \\
\text { salam } \\
(1) \\
\text { China } \\
(1) \\
\text { Japan } \\
(1) \\
\text { Malaysia } \\
\text { (5) } \\
\text { Philip- } \\
\text { pines } \\
\text { (1) } \\
\text { Demo- } \\
\text { cratic } \\
\text { People's } \\
\text { Repub- } \\
\text { lic of } \\
\text { Korea } \\
\text { (4) Viet } \\
\text { Nam (3) }\end{array}$ & 32 & 49.5 & 0.45 & $\begin{array}{l}\text { Allergist } \\
(46.8) \\
\text { Clinical } \\
\text { Immu- } \\
\text { nologist } \\
(21.8) \\
\text { Derma- } \\
\text { tologist } \\
(9.3) \\
\text { ENT } \\
(3.2) \\
\text { Paedia- } \\
\text { trician } \\
(12.5) \\
\text { Pulmo- } \\
\text { nologist } \\
(3.2) \\
\text { Re- } \\
\text { searcher } \\
(3.2)\end{array}$ & 46.8 & 40.6 & $\begin{array}{l}\text { Private } \\
(28.1) \\
\text { Public } \\
(40.6) \\
\text { Both } \\
(31.3)\end{array}$ & $\begin{array}{l}\text { Yourself } \\
(37.5) \text { A } \\
\text { staff } \\
\text { member } \\
\text { / insti- } \\
\text { tution } \\
(40.6) \\
\text { Nobody } \\
(18.7) \text { I } \\
\text { don't } \\
\text { know } \\
(3.2)\end{array}$ & $\begin{array}{l}\text { ICD-10 } \\
(+ \\
\text { adapta- } \\
\text { tion) } \\
(50) \\
\text { ICD-9 } \\
(+ \\
\text { adapta- } \\
\text { tion) } \\
(3.1) \\
\text { SNOMED } \\
\text { CT } \\
(6.2) \\
\text { Read } \\
\text { Codes } \\
(0.0) \\
\text { None } \\
(37.5) \\
\text { Other } \\
(3.2)\end{array}$ \\
\hline
\end{tabular}

Table 2: Responses to open ended questions from a web international survey fielded in 2019: what is expected by a classification system and what the ICD-11 is able to bring 
What is expected from a classification system $(\mathrm{N}, \%) * *_{2} 22$ responses

Inclusion of some missing allergic diseases $(220,75.3)$

Inclusion of the diseases with overlapping classification (example: Asthma induced by Aspirin) (187, 64.0)

Inclusion of explicit diagnostic criteria $(115,39.4)$

Inclusion of causes $(99,33.9)$

Inclusion of symptoms $(68,23.2)$

No suggestions $(13,4.4)$

Other $(15,5.1)$ 